\title{
RELATIONSHIP BETWEEN ENTERPRENUERIAL ORIENTATION AND PERFORMANCE OF FAMILY OWNED ENTERPRIES IN NAIROBI COUNTY.
}

\author{
Rachael Mugure Mburu ${ }^{1 *}$, Robert Gichira², Teresiah Kyalo ${ }^{3}$ \\ *1,2 Jomo Kenyatta University of Agriculture School of Business \\ ${ }^{3}$ Karatina University School of Business \\ *lEmail: rmugure07@yahoo.com
}

*Corresponding Author: -

Email: rmugure07@yahoo.com

\begin{abstract}
: -
Small and Medium Family-Owned Enterprises (SMFEs) are the engines of economic development through job creation and poverty reduction in any nation. Currently, the SMFEs sector in Kenya contributes over 70\% of the country's GDP. This is in spite of the challenges surrounding this vital sector including low performance as compared to non-family enterprises, high mortality rate especially after the founder exits, lack of finances among others. The study seeks to establish the relationship between entrepreneurial orientation and small and medium family-owned enterprises performance in Kenya. The specific objectives are to find out the role of innovativeness, risk taking and proactiveness in the performance of family-owned enterprises in Kenya. Parker's Theory of Proactiveness and Schumpeter's theory of innovation were the theoretical framework for this study. Cross sectional survey design was adopted. The study population was the manufacturing family-owned enterprises registered by Kenya Association of Manufacturers based in Nairobi City County. The respondents were the Founders, C.E. Os, Directors and Managers of the firms. Data was collected using a questionnaire and the quantitative data was analyzed by calculating the response rate with descriptive statistics such as mean, statistical deviation and proportion using Statistical Packages for Social Scientists (SPSS) version 21 and Microsoft Excel. Inferential data analysis was carried out by the use of factor correlation analysis to determine the strength and the direction of the relationship between the dependent and the independent variables. A regression model was fitted and hypothesis testing carried out using multiple regression analysis. Results of the study revealed a positive and significant relationship between innovativeness, risk taking and proactiveness on firm performance.
\end{abstract}

Keywords: Entrepreneurial, Orientation, Perfomance, Innovativeness, Risk taking, Proactiveness

\section{(a) $(\$)$}




\section{CHAPTER ONE: INTRODUCTION}

Both developing and developed countries are geared towards attainment of economic growth and development. This can be attained through efficient utilization of the available resources, thus there is need to devise measures to attain full employment. The promotion, establishment and growth of the SMEs will assist in creating employment and maximise on the utilisation of human and locally available resources (Cunningham and Rowley, 2007). Globally, Small and Medium Enterprises account for 99\% of businesses and 40\% to 50\% of GDP (Brown and Harris, 2010). Previous studies indicate that in both developed and developing economies SMEs contribute on average, $60 \%$ total employment and maximize the efficiency of the resource allocation and distribution by mobilizing and utilizing local, human and material resources (Ayyagari, Beck, and Demirgüç, 2007, Cunningham and Rowley, 2007).

Research shows that the SME concept was introduced in Kenya way back in 1972 by ILO but its until 1990s that the Government formulated ways of implementing it (Baseline Survey 1999). Today, the sector has taken a pivotal position in the country's development process especially in generation of employment, wealth creation and income opportunities to thousands of people across the country (Maragia, 2008, KIPPRA, 2007).

Ida and Mahmood (2011) argued that most large and established organizations source their goods and services from SMEs. They further postulated that with SMEs, there is continued dynamism, innovation, efficiency, faster feedback because of their small size, controlled chain of command and better customer service. With these characteristics, there are prospects for better performance and efficient service delivery as well as faster execution of any competitive advantage in its line of operations.

SME performance is mostly constrained by external and internal factors for example the business environment, dynamic and radical technological changes, inability to carry out research thus lower chances of innovation, inability to recruit competent and qualified human resources, capital to propel organizational growth, minimal barriers to entry in the market, avoidance of expenses related with patents and copyrights, limited sources of financing as well as lack of entrepreneurial skills (Mahmood and Hanafi, 2012).

According to a survey by PriceWater House Coopers (PwC), 2014 on family business in Kenya, growth prospects are high and strong. Their contribution to the country's GDP is between 50-70\% according to the Kenya Economic Survey 2010 (ROK, 2010). The enterprises benefit from agile decision making and an entrepreneurial mindset especially when they focus on strategies to support long term sustainability, professional management, skills development and innovation. This focus helps to offset some risks to growth like economic and political instability and inadequate access to skilled labour. The survey shows that $59 \%$ of family enterprises in Kenya have experienced sales growth over the past 12 months, $56 \%$ were hoping to grow steadily over the next 5 years while $32 \%$ planned to grow their businesses quickly and aggressively. $35 \%$ hopes to generate sales from exporting goods or services to foreign markets in five years' time particularly within East African region. With the economy attracting the right skills and talent, political instability and lack of innovation will be the key challenges to growth over the next 5 years (PWC, 2014).

\subsection{Problem Statement}

The entrepreneurial spirit is considered to be the engine for economic growth (Mohammad, Ramayah, Puspowarisito, Natalisa and Saerang, 2011). The economic environment of most nations remains dominated by family enterprises (Kuratko and Richard, 2004; Heck and Stafford, 2001). The enterprises constitute between 80 and $98 \%$ of all businesses in the world's free economies, generate 49-50\% of the GDP in the U.S. and more than 75\% in most other countries. They employ $80 \%$ of the U.S. workforce and more than $75 \%$ of the working population globally and have created $86 \%$ of all new jobs in the U.S. over the past decade (Poza, 2013. According to Lam, (2009) nearly 92\% of the businesses in the United States are all in the control of one family or the other. In Asia and Latin America, family businesses represent a prevalent form of entrepreneurship (Carney and Gedajlovic, 2002).

In many African countries the sector accounts for about $90 \%$ of all enterprises and over $80 \%$ of new jobs in any given country (Kiraka et al, 2013). This brings about increased competition, continuous technological breakthroughs and rapidly changing customer requirements (Shiu and Walker, 2007). This important contribution has in the recent times made the family business one of the highly concerned agenda in the global entrepreneurial development. Ramona, Hoy, Poutziouris, Steier (2008) asserts that family business is an emerging aspect of entrepreneurship which has evolved over the decades and is still in its developing stage. The Kenya Economic Survey 2010 (RoK, 2010) noted that the SME sector generated 87.6 percent of the total jobs generated in 2009. Family enterprises range from very small micro to very large corporate entities and they all make a remarkable contribution to generally the world's economy (Pearson and Marler 2010). Most people in developing countries have turned to self-employment to support themselves and their families (Ball, Geringer, Minor and McNett, 2010).

However, according to the Kenya National Bureau of Statistics (2011), 3 out of 5 SMFEs fail within the first few months after the retirement/death of the first-generation entrepreneurs or in the first 3 years of establishment. Among the challenges facing this sector include lack of entrepreneurship knowledge and skills, lack of innovation, competition from large players, price pressures, accelerated technological changes, succession and governance issues (Karanja 2012, Price Waterhouse Coopers, 2014). This implies that SMEs must possess the entrepreneurial spirit so that they are able to face these challenges successfully leading to enterprises performing well thereby ensuring their long-term survival. Previous studies on entrepreneurial orientation and firm performance have produced mixed findings. The relationship has been studied directly or indirectly (e.g. Davis et al., 2010; Grande et al., 2011; Hameed et al., 2011, Otieno, 2012), and through the inclusion of the moderating effect of several factors on this relationship. Some of the results point to a positive relationship between these two concepts while others showed a negative association between entrepreneurial orientation and firm performance, whereas Ambad and Abdul Wahab (2013) findings indicated a mixed result of the 
EO - performance relationship. Thus, EO - performance relationship are inconclusive and suggests the need for further research. This study therefore sought to find out whether there is any relationship between Entrepreneurial Orientation and performance of family-owned enterprises in Nairobi County.

\subsection{Objectives of the Study}

The main objective of the study was to find out the effect of entrepreneurial orientation on the performance of familyowned enterprises in Nairobi City County, Kenya. To achieve this, the study specifically sought to:

1. To examine the effect of innovativeness on the performance of family owned enterprise in Nairobi County,Kenya.

2. To determine the effect of risk taking on the performance of family owned enterprises in Nairobi County,Kenya.

3. To establish the effect of pro-activeness on the performance of family owned enterprises in Nairobi County,Kenya.

\subsection{Hypotheses}

H01. Innovativeness has no significant effect on family owned enterprises performance in Nairobi County,Kenya.

H02. Risk taking has no significant effect on family owned enterprises performance in Nairobi County,Kenya.

H03. Proactiveness has no significant influence on family owned enterprises in Nairobi County,Kenya.

\section{Chapter Two: Theoretical Development and Literature Review \\ 2.1.1 Parker's Theory of Proactiveness}

The confidence that one will be successful in an undertaking is especially important in proactive goal generation because being proactive entails a high potential psychological risk to the individual (Parker, 2006). A proactive goal involves a deliberate decision process in which the individual assesses the likely outcomes of his or her behaviour (Morrison and Phelps, 1999; Parker, Williams, 2006). Individuals must be certain that they can both initiate proactive goals and deal with their consequences before they act as well as see the value associated with being proactive to change a particular target.

Lakhani and Wolf (2003) argue that, pro-activity can be generated by intrinsic motivation. Motivation is important in proactive goal processes particularly for very long-term oriented proactive goals. Similarly, pro-activity can be motivated by an individual's experience, which helps him or her narrow focus to an activity that fully occupies him/her ignoring the time taken, fatigue, and everything else but the activity (Rousseau and Vallerand, 2008). Proactive goals are not only linked to current identities but also are motivated by future-oriented identities (Strauss, Griffin, and Rafferty, 2009). Like other possible future and past identities, future work will serve as a standard against which the present self can be compared (Carver and Scheier, 2008) and constitute motivational resources that individuals can use in the control and direction of their own actions (Oyserman and Markus, 2009). Strauss, Griffin, and Rafferty, (2009) showed that future work pertaining to individuals' careers motivated greater proactive career-oriented behaviour. In family enterprises for example, the entrepreneur must be proactive in order to start and grow his/her business to the highest level possible. He is fully immersed in running his business considering the past and the present experiences and predicting the future of his enterprise. The entrepreneur takes risks, sacrifices his time, energy, family time and others for the sake of his business performance.

\subsubsection{Schumpeter Theory of Innovation}

According to Schumpeter (1934), a dynamic entrepreneur is the person who innovates, who makes "new combinations" in production. He argues that an entrepreneur disrupts markets and causes new ones to be formed in circular flows. The 'true' entrepreneur causes a radical change that is discontinuous with the previous flows by obtaining and using information caused by these 'tides of creative destruction'. He describes innovation as ; the creation of a new good or new quality of good; creation of a new method of production; the opening of a new market; the capture of a new source of supply; a new organization of industry (e.g., creation or destruction of a monopoly).

Schumpeter observes that people act as entrepreneurs only when they actually carry out new combinations, and lose the character of entrepreneurs as soon as they have built up their business, after which they settle down to running it as other people run their businesses (Schumpeter, 1939). For Schumpeter (1939), an entrepreneur is not only an innovator but also a leader. Since the main characteristic of an entrepreneur is innovation and leadership, Schumpeter's entrepreneur does not necessarily start his own business and does not have risk- taking as one of his functions, (Tarabishy, Lloyd and George, 2005). Adam Smith in Wealth of Nations argues that innovation requires the investment of money and that its an important economic activity inducing gains. Therefore Schumpeter (1942) believed that larger firms are more innovative than smaller firms. This theory was further refined by Galbraith (1952). The main objective of firms is to maximize profits. Larger firms are able to achieve economies of scale, diversify, develop market reputation etc. as shown by empirical studies, (Scherer 1965, Cohen and Klepper 1996). Nelson (1959) argues that the more widespread the reputation and name of firm, the higher the chances of full exploitation of its research efforts. The empirical analysis of Schmookler (1972) showed that after a certain 'large' size the efficiency of an inventive activity varies inversely with firm size. Williamson (1965) further explains the factors which hinder innovation in a large firm. The 'scarcity of ideas' is another reason why large firms are less innovative. Hicks and Buchenan (2003) argue that smaller firms are in a better position to exploit an innovation combined with their focus on new innovative technologies. Smaller firms are also more efficient in the use of capital and labour resources (Acs and Audretsch 1991). However both large and small firms exhibit advantages and disadvantages. An innovation study carried out in some Latin American firms (Arocena and Sutz, 2000) finds that little is invested in innovative activity. According to Kumar and Saqib (1996), in India, a study on small and medium-sized firms finds that vertical integration, export orientation 
and competitive pressures heighten the need for spending on Rand. This means that innovation is the key to SMEs growth and development especially in the developing nations, Kenya included. In today's business world, technological advancement has changed how business is done, brought about shorter product life cycles, customer awareness among others. This translates that family owned and non-family owned businesses must come up with strategies requiring their enterprises to continually innovate and to quickly adapt and renew their strategies in order to retain their competitive edge.

\subsection{Conceptual Framework}

A diagrammatic presentation showing the relationship between dependent and independent variables is known as conceptual framework (Kothari, 2011). In the current study the dependent variable; performance of family owned enterprises was operationalized as increase in sales volume and the net profit of the firm. The independent variable entrepreneurial orientation was operationalized with three constructs which are innovativeness; introduction of new products, adoption of new technology, risk taking; entrance into new markets, profit sacrifices made on entrant into new markets and proactiveness; identification and exploitation of new opportunities and adoption of new modes of payment.

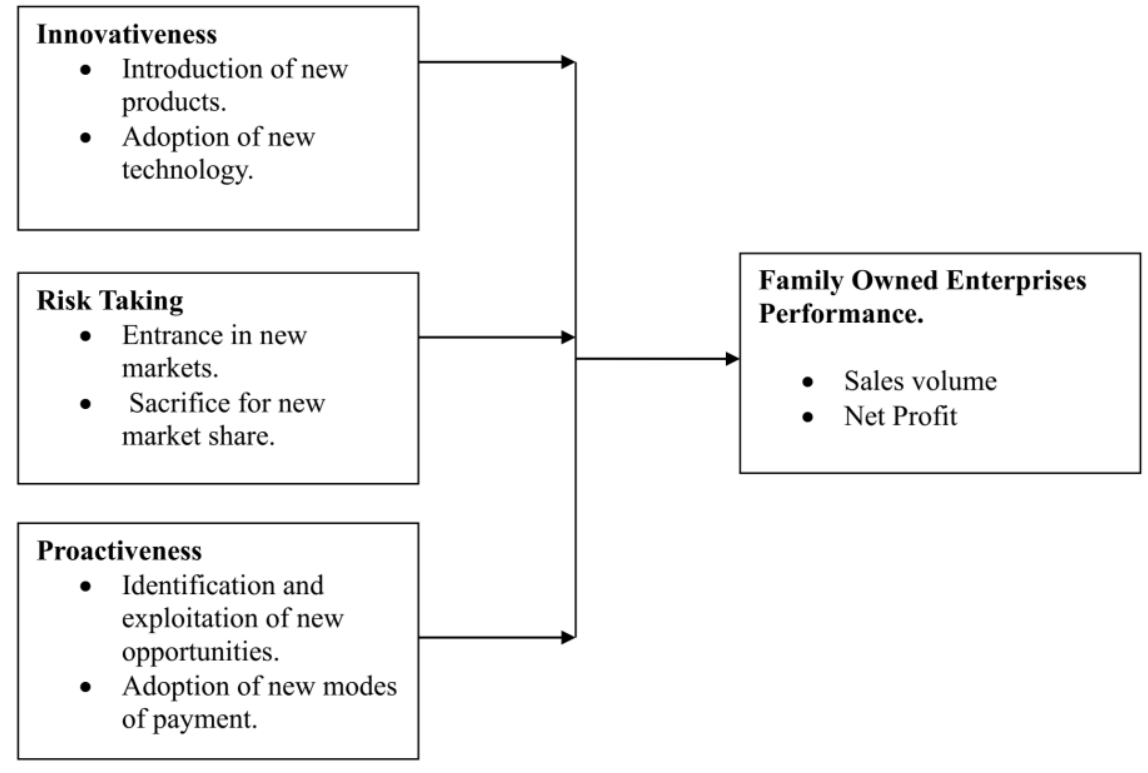

Independent Variables

Figure 1 Conceptual Framework

\subsection{Empirical Review \\ 2.3.1 Innovativeness}

Ali and Abdel (2014) studied entrepreneurial orientation among women owned enterprises in Somalia in relation to firm performance. A sample of 200 women companies were purposively selected to fill the questionnaires. The study purposed to specifically measure the impact of innovativeness, proactiveness and risk taking. Firm performance was measured by use of six indicators, namely market share, sales growth, profit to sales ratio, market development and new product development. Innovativeness was measured using changes in products or service line.

Correlation analysis for innovation and firm performance was found to have a significant and weak positive relationship, and findings from regression analysis produced similar results supporting Yong, Jing and Ming (2008).

An increased performance can be achieved by small firms if they invest well in innovativeness. This emphasis was laid by a Hilgers (2011) who studied the relationship between international EO and firm performance in Netherlands' small manufacturing firms. A multiple-case research design was adopted for increased generalizability and power in explanation (Miles and Huberman, 1984). Hilgers sampled only 6 of small manufacturing firms by conducting an interview whereby innovativeness was indicated by new ideas generated, development for employees through training and introduction for the new product by use of technology. The study measured firm performance by use of profit and sales goal achievement. Results of the findings indicated that innovativeness contributed largely in influencing firm performance positively as compared with other firms' dimensions namely proactiveness, risk taking, competitive aggressiveness and autonomy.

Kimani (2015) studied the effect of adoption of financial innovation on SMEs performance in Kenya. The population of the study was the registered SMEs by Kenya Revenue Authority (KRA). A total of 487 were chosen as the appropriate sample size. The findings revealed a positive relationship between the adoption of financial innovation and performance of SMEs in Kenya.

\subsubsection{Risk Taking}

Kiprotich, Kimosop and Kemboi (2015) assessed the relationship between risk taking and Small and Medium Enterprises (SMEs) performance in Nakuru County (Kenya). Explanatory research design was adopted and a sample of 214 SMEs was selected by stratified sampling method. Primary data was collected using questionnaires. Though the 
study showed a moderate positive relationship, it was found that risk-taking has no significant effect on SME performance contrary to previous studies by Ali andAbdel (2014); Verhees, Klopic and Kuipers (2008) which had revealed a positive and significant relationship.

Wiklund (2010) studied risk taking and family firms in Sweden by taking a sample of Swedish SMEs. The study found that risk taking is an important dimension of EO in family enterprises and is positively associated with proactiveness and innovation. According to the study, family firms do take risks while engaged in entrepreneurial activities to a lesser extent as compared to non-family firms and that risk taking is negatively related to performance.

\subsubsection{Proactiveness}

Several studies have been conducted to try and establish the relationship of this factor with the firm performance: In a sample of 308 street traders in Johannesburg (South Africa), Venter and Callaghan (2011) tested the relationship of proactiveness and firm performance. Proactiveness was assessed as growth willingness of the participants. Results of this study confirmed that there is a positive and significant association between proactiveness and informal sectors performance hence supporting Mueller (2008) and De Clerq and Rouis (2007).

Research conducted by Yong, Jing and Ming (2008) examined the entrepreneurship orientation and firm performance from a population of the listed Taiwan Securities and Futures Institutes. Data was collected from 165 valid mailed questionnaires. A cross-sectional research design was employed. Firm performance was assessed by efficiency, growth and profit. Proactiveness was measured by how firms relate to market opportunities by taking down initiatives in the marketplace. The findings in this study were in agreement with Lumpkin and Dess (1996) that there is positive relationship between proactiveness and firm performance.

Kraus et. al. (2011) studied the effects of entrepreneurship orientation and business performance of SMEs in Netherlands during periods of economic crisis and the severe environmental turbulence that accompany such crisis. This was a quantitative study and a multi-dimensional model of EO was used. Data was collected using email survey method from 164 Dutch SMEs. The findings showed that proactive firm behaviour positively contributes to SMEs performance during economic crisis while innovative SMEs perform better in turbulent environments but those innovative enterprises should minimize the level of risk and avoid very risky projects.

\section{Chapter Three: Research Methodology \\ 3.1 Research Design}

A step-by-step procedure indicating how the study objectives will be achieved is known as research design (Orodho, 2009). Kerlinger and Lee (2000) viewed the research as a strategic plan which aims at answering the research questions with minimal deviations. In the current study, cross sectional survey research design was used because it explains the current phenomenon through the use of systematic and controlled methods in data collection (Mugenda and Mugenda, 2003). The design was appropriate for the current study since it sought to examine the effect of entrepreneurial orientation on the performance of family-owned enterprises in Nairobi City Count, Kenya.

\subsection{Population of the Study}

Population refers to the entire group of people or objects of interest that the researcher wishes to investigate, Sekaran (2010). Mugenda and Mugenda (2003) defines population as an entire group of individuals or objects having common observable characteristics. It is the aggregate of all that conforms to a given specification. Bryman and Bell (2003) define population as basically the universe of units from which the sample is to be selected In this study, the population of interest was the registered family owned small and medium manufacturing enterprises by Kenya Association of Manufacturers located in Nairobi City County. However, there are no records distinguishing family and non-familyowned enterprises during business registration process in Kenya. The situation is not only found in Kenya but also in other countries. According to Floren 2003 and Venter 2003, the unavailability of family enterprises databases and their secretive nature makes the field of family businesses a challenging area of study. Therefore, the only option is to make a preliminary survey of those enterprises registered under KAM to ascertain they are family businesses as per the operational definition of family business. This is a common practice among family business studies facing unreliable database in many countries (Venter 2003). The population of the study was based on the listed KAM (2015) members in the manufacturing and production sectors based in Nairobi County. This is because they are in the same area and are exposed to the same business environment. The sectors include: Chemical and Allied 69, Foods and Beverages 174, Pharmaucetical and Medical Equipment 20, Textiles and Apparels 60, Metal and Allied 80 and Footwear and Leather 7. This provided a suitable representation of the Kenyan economy with varied representation of business ownership hence justifying the selection of this study.

\subsection{Sample size and Sampling Technique}

A subset of the total population which can act as a true representative is known as a sample (Oso and Onen, 2009). There are two types of sampling technique, non-probabilistic and probabilistic. In the case of non-probabilistic sampling, the respondents are selected subjectively while in probabilistic sampling, all respondents have an equal chance of being selected (Oso and Onen, 
2009). The study adopted non probability convenience sampling procedure, a process of acquiring sampling units or people who are most conveniently available. This is an effective way of obtaining a large number of completed questionnaires (Zikmund 2005). The sampling technique has been used by other researchers who have faced the challenge of lack of a national database on family businesses (Sonfield and Lussier 2004; Van Der Merwe and Ellis 2007).

Simple random sampling will be used to select 201 SMFEs. According to Orodho (2005), simple random sampling ensures that each unit has an equal probability of being chosen, and the random sample is the most representative of the entire population and least likely to result in bias. It has statistical properties that allow the researcher to make inferences about the population, based on the results obtained from the sample. The necessary sample size was derived from the formulae:

$$
\mathrm{n}=\frac{\mathrm{Z}^{2} \cdot \sigma(1-\sigma)}{\mathrm{e}^{2}}
$$

Where:

- $\mathbf{n}$ is the sample size

- $\quad \mathbf{Z}$ is the Z-score and for the purpose of this study was 1.96 in order to have a $95 \%$ confidence level

- $\boldsymbol{\sigma}$ is the Standard of Deviation and to be safe the decision is to use 0.5 as this ensured that the sample was large enough.

- $\mathbf{e}$ is the margin of error and for the purpose of this study one construed to give a confidence interval of $+/-5 \%$.

Mathematically the study considered 201 respondents were drawn from the study target population. Since all the respondents were from Nairobi County, Kenya, stratified sampling technique was used to draw the respondents as shown in Table 1, as per the sector in which the family enterprise operates.

Table 1 Sample Size

\begin{tabular}{cccc}
\hline Sector & Target population & Percentage of the total & Sample \\
\hline Chemical and Allied & 69 & 16.9 & 34 \\
Food and Beverages & 174 & 42.4 & 85 \\
Pharmaceutical and Medical Equipment & 20 & 4.9 & 10 \\
Leather and Footwear & 7 & 1.7 & 4 \\
Textiles and Apparels & 60 & 14.6 & 29 \\
Metal and Allied Sector & 80 & 19.5 & 29 \\
\hline Total & $\mathbf{4 1 0}$ & $\mathbf{1 0 0}$ & $\mathbf{2 0 1}$ \\
\hline
\end{tabular}

\subsection{Data Collection Instrument}

Questionnaires were self-administered and two research assistants were recruited and trained so that they were able to get quality results. The target participants were the SMEs Founders, the C.E.Os, the Directors and the Managers. These target participants was easy to identify, and they fully understand the enterprises mission and vision, growth history, the strategies adopted in the past, present and the future prospects in order to ensure the continued performance of the enterprises.

The enterprises was first be contacted and the intention to drop the questionnaires and the request to do so explained to the C.E.Os/Managers. The research assistants delivered the questionnaires to the respondents and wait for them to be filled. Respondents who were not in a position to fill questionnaires that day, were given a week after which the research assistants returned to collect them. The number of questionnaires that were utilized to collect data for this study will be 201 .

\subsection{Data Processing and Analysis}

Sekaran (2003), indicates that there are three objectives in data analysis which include: - a) getting a feel for the data. A feel for the data gives the researcher an idea of how well the respondent have reacted to the questions in the questionnaire and how good the questions or items and measures are. This includes descriptive statistics such as the response rate, mean and standard deviations of the observed variables, b) testing the goodness of the data. Establishing the goodness of the data gives credibility to subsequent analysis and findings since it measures the reliability and validity of the measures used in the study, and c) testing hypotheses developed for the research. When the data is ready for analysis, the researcher is ready to test the hypothesis already developed using appropriate statistical tests (Sekaran, 2003).

The quantitative data collected will be analyzed by calculating response rate with descriptive statistics such as mean, median, standard deviation and proportions using Statistical Package for Social Sciences (SPSS) version 21 and Microsoft Excel. Inferential data analysis will be carried out by the use of factor analysis and correlation analysis to determine the strength and the direction of the relationship between the dependent variable and the independent variables. Regression model was fitted and hypothesis testing carried using multiple regression analysis and standard $\mathrm{F}$ tests and $\mathrm{t}$ tests.

Mugenda and Mugenda (2008), states that multiple regression analysis attempts to determine whether a group of variables predict a given dependent variable and hence attempt to increase the accuracy of the estimate. The multiple 
regression model for this study will be as follows: Multiple linear regression model with dependent variable (Y) - firm performance, independent variables X1 (Innovativeness), X2 (Proactiveness), X3 (Risk taking), was used to show whether the stated independent variables significantly influence employee productivity. The regression model is as illustrated:

Where

$$
\mathrm{Y}=\beta 0+\beta 1 \mathrm{X}_{1}+\beta_{2} \mathrm{X}_{2}+\beta_{3} \mathrm{X}_{3}+\varepsilon
$$

$\mathrm{Y}=$ Firm Performance, $\beta_{0}=$ Constant, $\beta \underset{\sim}{\mathrm{i}}=$ is the coefficient for $\mathrm{X}_{\mathrm{i}}$ (Where $\mathrm{i}=1,2,3$ ), $\mathrm{X} 1=$ Innovativeness, $\mathrm{X} 2=$ Proactiveness, $\mathrm{X} 3=$ Risk taking, $\varepsilon=$ Error term

\section{Chapter Four: Research Findings}

The main objective of the study sought to examine the effect of entrepreneurial orientation on performance of familyowned enterprises. The study adopted three constructs of EO; innovativeness, risk taking and proactiveness.

\subsection{Innovativeness and Performance of Family Enterprises}

The first objective of the study sought to examine the effect of innovation on performance of family-owned manufacturing enterprises in Nairobi. Since the data was in ordinal scale, mean, standard deviation, frequency and percentages were used to analyse the data as summarized in Table 2. Majority 38.3\% agreed, 14.3\% strongly agreed and $10.2 \%$ disagreed that they prefer to scan market and come up with new and updated products. Secondly, $37.8 \%$ agreed, $22.4 \%$ strongly agreed and $6.1 \%$ strongly disagreed that changes in their products had been many both in design and type. Thirdly, $41.8 \%$ agreed, $25 \%$ strongly agreed and $10.2 \%$ disagreed that their firm encourages and support and innovative ideas and always act on them.

Majority $39.3 \%$ agreed and $38.3 \%$ strongly agreed that their firm's encourages use of current production methods and process. Moreover, 36.2\% agreed, 33.2\% strongly agreed and 9.7\% strongly disagreed that their firms always adopt latest technology in the market. Finally, majority $45.4 \%$ agreed, $14.8 \%$ strongly agreed and $11.2 \%$ disagreed that their firms puts strong emphasis on research and development and improvement of the current products and services.

Table 2 Innovativeness and Performance of Family Enterprises

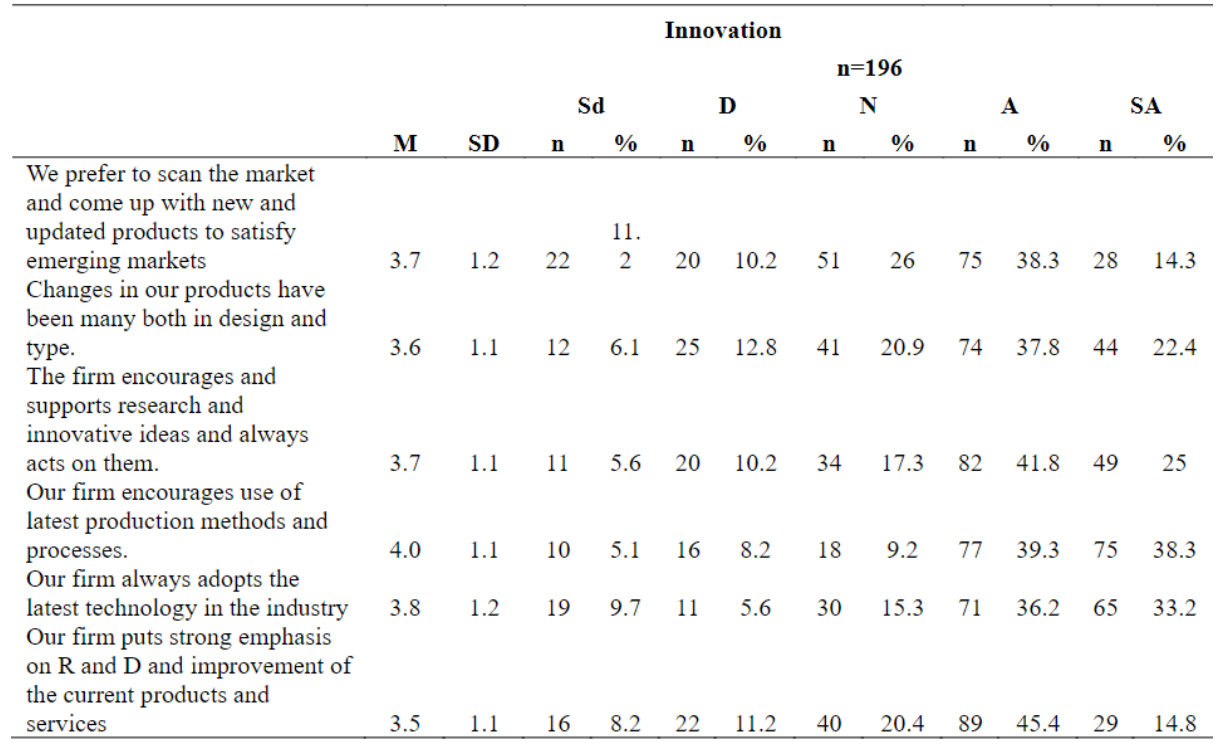

*M-Mean SD - Standard deviation, n-Frequency, \%-Percentage Sd-Strongly disagree, D-Disagree, N-Neutral, AAgree, SA-Strongly agree

\subsection{Risk Taking and Performance of Family Enterprises}

The second objective of the study sought to determine the effect of risk taking on the performance of family-owned enterprises. To achieve this objective primary data was analyzed using mean, standard deviation, frequency and percentage. Results in Table 3 reveal that majority (mean $=3.7$, Standard deviation=1.2) agreed that their firm has a strong inclination for low-risk projects (with normal and certain rates of return). Secondly, majority $30.1 \%$ agreed and $21.4 \%$ strongly agreed that, their management does not hesitate to take loans for new project ventures. Thirdly, majority agreed $($ mean $=4.2$, standard deviation $=1.4$ ) that their firm has strong inclination towards projects with high rates of return.

In addition, $56.1 \%$ strongly agreed that their firm does not shy away from funding new methods and processes even if they have not been tested in the market and may be risky. Finally, 43.4\% agreed, 36.7 strongly agreed and $7.7 \%$ disagreed that their firms goes to the extent of sacrificing profit to gain market share. 
Table 3 Risk Taking and Performance of Family Enterprises

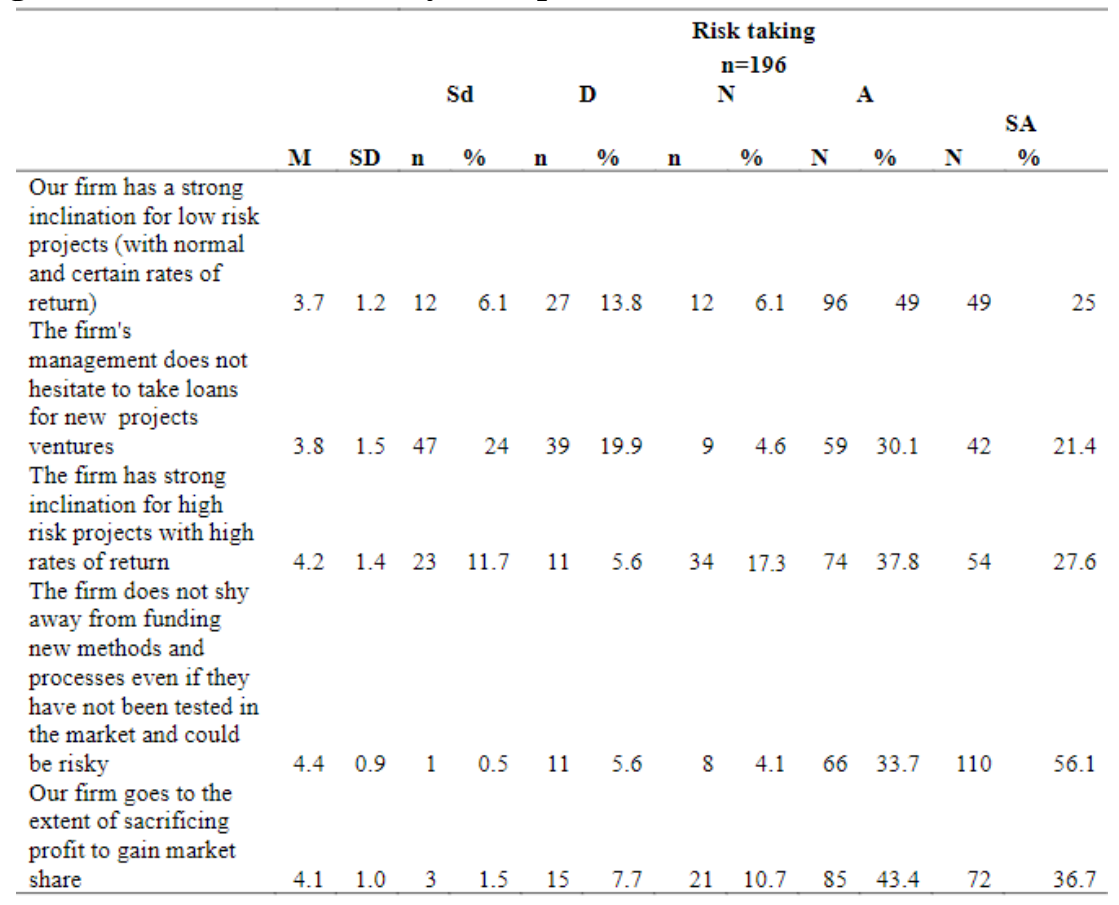

*M-Mean SD - Standard deviation, n-Frequency, \%-Percentage Sd-Strongly disagree, D- Disagree, N-Neutral, AAgree, SA-Strongly agree

\subsection{Proactiveness and Performance of Family Enterprises}

The third objective of the study sought to establish the effect of proactiveness on the performance of family-owned enterprises. To achieve the respondents were requested to rate responses on a five-point likert scale and the responses were summarized as shown in Table 4 using mean, standard deviation, frequency and percentage. Majority (mean =3.9) agreed that compared to other businesses in the same field they are usually among the first to introduce new products and new methods of production in the market. Secondly, $45.4 \%$ strongly agreed and $39.3 \%$ agreed that their firm always tries to be among the leading establishments in the market place to change procedures of production and other activities in order to lead the market. Thirdly, 51.5\% strongly agreed and $41.8 \%$ agreed that they monitor the market and responds more rapidly to the changes than their competitors. Finally, $45.4 \%$ agreed and $40.3 \%$ strongly agreed that they ensure that their firm has adopted the latest modes of payment.

Table 4 Proactiveness and Performance of Family Enterprises

\begin{tabular}{|c|c|c|c|c|c|c|c|c|c|c|c|c|}
\hline & \multirow[b]{4}{*}{$\mathbf{M}$} & \multirow[b]{4}{*}{ SD } & \multicolumn{10}{|c|}{$\begin{array}{c}\text { Proactiveness } \\
n=196\end{array}$} \\
\hline & & & \multicolumn{2}{|c|}{ Sd } & \multicolumn{2}{|c|}{$\mathbf{D}$} & \multirow{2}{*}{\multicolumn{2}{|c|}{$\mathbf{N}$}} & \multirow{2}{*}{\multicolumn{2}{|c|}{$\mathbf{A}$}} & \multicolumn{2}{|c|}{ SA } \\
\hline & & & & & & & & & & & \multirow[b]{2}{*}{$\mathbf{n}$} & \multirow[b]{2}{*}{$\%$} \\
\hline & & & $\mathbf{n}$ & $\%$ & $\mathbf{n}$ & $\%$ & \multicolumn{2}{|r|}{$\%$} & $\mathbf{N}$ & $\%$ & & \\
\hline \multicolumn{13}{|l|}{ Compared to other } \\
\hline \multicolumn{13}{|l|}{ businesses in the same } \\
\hline \multicolumn{13}{|l|}{ field we are usually } \\
\hline \multicolumn{13}{|l|}{ among the first to } \\
\hline \multicolumn{13}{|l|}{ introduce new products } \\
\hline \multicolumn{13}{|l|}{ and new methods of } \\
\hline production in the market & 3.9 & 1.1 & 7 & 3.6 & 19 & 9.7 & 24 & 12.2 & 75 & 38.3 & 71 & 36.2 \\
\hline \multicolumn{13}{|l|}{ The firm always tries to } \\
\hline \multicolumn{13}{|l|}{ be among the leading } \\
\hline \multicolumn{13}{|l|}{ establishments in the } \\
\hline \multicolumn{13}{|l|}{ market place to change } \\
\hline \multicolumn{13}{|l|}{ procedures of production } \\
\hline \multicolumn{13}{|l|}{ and other activities in } \\
\hline order to lead the market & 4.2 & 0.9 & & & 13 & 6.6 & 17 & 8.7 & 77 & 39.3 & 89 & 45.4 \\
\hline \multicolumn{13}{|l|}{ The firm monitors the } \\
\hline market and responds & & & & & & & & & & & & \\
\hline more rapidly to the & & & & & & & & & & & & \\
\hline changes than our & & & & & & & & & & & & \\
\hline competitors & 4.4 & 0.7 & 1 & 0.5 & 2 & 1 & 10 & 5.1 & 82 & 41.8 & 101 & 51.5 \\
\hline We ensure that the firm & & & & & & & & & & & & \\
\hline has adopted the new & & & & & & & & & & & & \\
\hline payment modes & 4.2 & 0.8 & 2 & 1 & 7 & 3.6 & 19 & 9.7 & 89 & 45.4 & 79 & 40.3 \\
\hline
\end{tabular}

*M-Mean SD - Standard deviation, n-Frequency, \%-Percentage Sd-Strongly disagree, D- Disagree, $N$-Neutral, AAgree, SA-Strongly agree 


\subsection{Correlation and Regression Analysis}

Correlation analysis was used to examine the strength of the relationship between innovativeness, risk taking, proactiveness, and firm performance. To achieve this, Product moment correlation coefficient was used as the measure of the strength of the relationship since both dependent and independent variables were in ratio scale. According to Kothari (2004; Olesia, 2015), product moment correlation should be carried out if and only if both dependent and independent variables are in either ratio or interval scale. Correlation coefficient is measured by rho ranges between $-1<$ rho $<+1$. The more close the coefficient is to either +1 or -1 the stronger the relationship and vice versa. A negative coefficient indicates an increase in one variable is associated with a decrease in another variable while a positive coefficient indicates an increase in dependent variable is associated with an increase in the independent variable.

There was a positive and significant relationship between innovativeness and firm performance (rho $=0.202$, $\mathrm{p}$ value < 0.05). This implies that a unit change in innovation increases firm performance by 0.202 units. Secondly, there was a strong positive and significant relationship between risk taking and firm performance (rho $=0.834$, $p$ value $<0.05$ ). This implies that a unit change in risk taking increases firm performance by 0.834 units. Thirdly, there was a strong positive and significant relationship between proactiveness and firm performance ( $r h o=0.882$, $p$ value $<0.05$ ). This implies that a unit change in proactiveness increases firm performance by 0.882 units.

Table 5 Correlation Analysis

\begin{tabular}{ccccc}
\hline & Firm Performance & Innovation & Risk Taking & Pro activeness \\
\hline Firm Performance & 1 & $.202^{* *}$ & $.834^{* *}$ & $.882^{* *}$ \\
Innovativeness & & 1 & 0.093 & 0.052 \\
Risk Taking & & & 1 & $.584^{* *}$ \\
Pro activeness & & & & 1 \\
\hline
\end{tabular}

\subsubsection{Regression Analysis}

An R squared of $94.8 \%$ shows that $94.8 \%$ of the changes in family owned enterprises can be explained by innovativeness, risk taking and proactiveness. The three attributes of entrepreneurial orientation had a significant influence on firm performance as indicated by $\mathrm{F}(3,192)=1173.086$, $\mathrm{p}$ value $=0.00$.

The first hypotheses of the study hypothesesed that there is no significant relationship between innovation and family owned enterprises performance. Results of the study revealed a positive and significant relationship between innovativeness and firm performance $(\beta=0.202, \mathrm{p}$ value $<0.05)$. This implies that a unit change in innovativeness increases firm performance by 0.202 units while holding all other factors constant.

The second hypotheses stated risk taking had no significant influence on family owned enterprise firm performance. Results of the study revealed a positive and significant relationship between risk taking and firm performance, $(\beta=$ 0.834 , $\mathrm{p}$ value $<0.05$ ). This implies that a unit change in risk taking increases firm performance by 0.834 units.

The third hypotheses stated that there was a significant relationship between proactiveness and family owned firm performance. Results of the study revealed a positive and significant relationship between proactiveness and firm performance, $(\beta=0.88, \mathrm{p}$ value $<0.05)$. This implies that a unit change in proactiveness increases firm performance by 0.88 units.

Table 6 Regression Analysis

\begin{tabular}{|c|c|c|c|c|c|}
\hline \multicolumn{6}{|c|}{ Model Summary } \\
\hline $\mathbf{R}$ & R Square & $\begin{array}{l}\text { Adjusted R } \\
\text { Square }\end{array}$ & $\begin{array}{l}\text { Std. Error of the } \\
\text { Estimate }\end{array}$ & & \\
\hline .974 & 0.948 & 0.947 & 0.229222 & & \\
\hline \multicolumn{6}{|c|}{ ANOVA } \\
\hline & $\begin{array}{l}\text { Sum of } \\
\text { Squares }\end{array}$ & df & Mean Square & $\mathbf{F}$ & Sig. \\
\hline Regression & 184.912 & 3 & 61.637 & 1173.086 & 0.000 \\
\hline Residual & 10.088 & 192 & 0.053 & & \\
\hline Total & 195 & 195 & & & \\
\hline \multicolumn{6}{|c|}{ Coefficients } \\
\hline & \multicolumn{2}{|c|}{ Unstandardized Coefficients } & $\begin{array}{l}\text { Standardized } \\
\text { Coefficients }\end{array}$ & & \\
\hline & B & Std. Error & Beta & $\mathbf{T}$ & Sig. \\
\hline (Constant) & $1.10 \mathrm{E}-17$ & 0.016 & & 0.00 & 1 \\
\hline Innovativeness & 0.202 & 0.016 & 0.202 & 7.706 & 0.00 \\
\hline Risk Taking & 0.834 & 0.02 & 0.834 & 23.253 & 0.00 \\
\hline Pro activeness & 0.88 & 0.02 & 0.88 & 29.671 & 0.00 \\
\hline
\end{tabular}




\section{Chapter Five Discussion, Conclusion and Recommendations 5.1 Discussion and Conclusion}

The results on the impact created by innovativeness on the family business performance have not only been found to be positive but also significant. This means that for a higher performance in the family-owned businesses, a higher level of innovativeness, as depicted in the act of producing new products or offering unique services from time to time, finding novel solutions to the upcoming challenges and by the use of new techniques in administration and operations, need to be observed. This study has shown the relevance of hiring innovative employees and tactics to help increase the sale volume and profit to be realized by the business. Just like Hilgers (2011) who studied Netherlands' manufacturing firms, innovative businesses performed better than other firms that adopted different dimensions of EO.

Similarly, the current study confirms the finding of Ali and Abdel (2014) and Yong et al., (2008) that found innovative businesses do have a weak positive relationship with firm performance. Further, despite Verhees' et al., (2008) study failing to establish whether the creative / innovation has significant impact on the firm performance they seem to agree to this study that the relationship exhibited by the two variables is positive.

In addition, a firm that able to offer a new combination in their output generation and those that complements customers with advanced service will always win the hearts of their customer and hence the increase in sales volume and ultimately profits. A finding in this study concurs with Schumpeter's theory of innovation of 1939 which pointed out that an enterpreneur must act innovatively to cause radical changes that continue to happen in a circular flow.

Motivation to earn attractive returns has been the quest why many enterpreneurs engage in risk taking behavior that if executed as planned will result in high returns otherwise it would be a disaster in waiting. A wise investor would only undertake a calculated and tolerable level of risk to remain on the safe side (Brockhaus, 1980). The results of the study have shown risk taking to have a significant and strong positive association with performance of family owned enterprises. This findings agree with Ali and Abdel (2014) study that found a significant and positivelinkage.

Wiklund's (2010) study compared family owned and non-family owned Swedish enterprises and discovered that the difference between their performance was majorly determined by risk taking dimension. Performance of family owned business differed in that they tend to take less risk as they perceive a higher level of risk to be detrimental in case the worst happens. Unlike their counterpart, non-family owned enterprises consider risk taking positively based on the returns expected whenever there is a change in the level of risk. Contrary to this study findings, an explanatory study of SMEs performance in the Nakuru County by Kiprotich et al., (2015) revealed that risk taking behaviour has insignificant effect even though there exists a moderate positive effect on SMEs performance.

Proactiveness as demonstrated by how enterprises identify and exploit new opportunities and the way new modes of payment are adopted had a significant and positive relationship with the performance of the family owned businesses. This agrees with the Venter and Callagan (2011) study of South African traders that found similar study when regression analysis was conducted on the data about the traders. Many of the firms those were willing to grow, especially in the informal business sectors. Small businesses are in most case planned to small start based on the principle of "think small and grow big" hence the high rate of proactiveness will better to explain the increase in performance of such ventures/enterprises.

Assessing how firms explore market opportunities through the projects initiated over time are clear indicate for the firms that are proactive. Using the same notion Yong et al., (2008) observed that firms listed in Taiwan exhibit proactiveness that can be related positively to firm own performance thus confirming the current study findings. With an expounding fact from Dutch SMEs, Kraus et al., (2011) argues that irrespective of the environment under which firm continued to operate proactiveness will in most cases if not all yield positive returns, even in economic turbulent moments. Mentzer et al., (2008) echoes that SMEs proactiveness is another strong strategy that uniquely relies on how the marketing and sales resources, skills and processes takes place.

\subsection{Recommendations}

The first objective was to examine the effect of innovativeness on the performance family owned enterprises. The study findings indicated that innovativeness has an effect on the performance of family owned enterprises. The researcher thus recommends that SMEs owners should now more than ever, regard the innovation process as one of the priorities in their organisation's strategies. The shorter product life cycle, the stiff competition, the ever changing technology, increase in customer's tastes, preferences and demands leaves enterprises with no choice but to continually innovate in order to sustain their businesses.

The second objective was to determine the effect of risk taking on the performance of family owned enterprises. The study findings are that risk taking influences firm's performance. Globalization, liberalization and other forces have changed how business is done today. The researcher recommends that SMFEs should not shy away from taking well calculated risks to enhance their business performance.

The third objective was to establish the effect of pro-activeness on the performance of family owned enterprises. The study reveals that pro-activeness positively affects a firm's performance. The researcher recommends that SMFEs should always be on the ground so that they are able to detect the changing trends in their markets and thus proactively satisfy their customer's needs. This will ensure that they will be among the first to benefit from the new ideas or innovations thus becoming the market or industry leaders. This can be achieved through visiting trade fairs, workshops, seminars and following the latest trends in their environment.

\section{References}

[1].Ali, Y. S., and Abdel, H. A. (2014). Entrepreneurial orientation and Performance of Women Owned and Managed 
Micro and Small Enterprises in Somalia. ZENITH International Journal of Multidisciplinary Research. Vol.4 (1).

[2].Asadi, F., Mozafari, A. A., and Zarei, A. (2015). The Relationship between Competitive Advantage and Organizational Performance from the Experts of Iranian Ministry of Sport and Youth's Perspective . Int. J. Rev. Life. Sci., 1147-1152.

[3].Atalay, M., Anafarta, N., and Sarvan, F. (2013). The Relationship between Innovation and Firm Performance: An Empirical Evidence from Turkish Automotive Supplier Industry. Procedia - Social and Behavioral Sciences, 75, 226-235. http://dx.doi.org/10.1016/j.sbspro.2013.04.026.

[4].Azizi Roslan et al (2014) The Relationship between Entrepreneurial Orientation and Business Performance of SMEs in Malaysia. International Journal of Management Excellence.

[5].Bamford C.E., Dean T.J., McDougale P.P., (2000) An examination of the impact of initial founding conditions and decisions upon the performance of new bank startups. J Bus Ventur 15(3):253-277

[6].Barney, J. (1991). Firm Resources and Sustained Competitive Advantage. Journal of Management, 17(1), 99-120. http://dx.doi.org/10.1177/014920639101700108

[7].Begley,T.M and Boyd D.P. (1987), Psychological Characteristics associated with perfomance in entrepreneurial firms and small businesses.Journal of Business Venturing 2,79-93.

[8].Bukhamsim, M. (2015). Investigating the Relationship between Organizational Innovation Capability and FirmPerformance with Irish SMEs. Duplin Institute of Technology.

[9].Bwisa H.M. (2011) Entrepreneurship Theory and Practice:A Kenyan Perspective.The Jomo Kenyatta Foundation, Nairobi.

[10]. Callaghan, C., and Venter, R. (2011). An investigation of the entrepreneurial orientation, context and entrepreneurial performance of inner-city Johannesburg street traders. Southern African Business Review Vol. 15 No. 1.

[11]. Coon,D. 2004 Introduction to Psychology ( $9^{\text {th }}$ Edition) Minneapolis; West Publishing Company. Eniola, A. A. (2014). SME firms performance in Nigeria: Competitive advantage. International Journal of Research Studies in Management, vol 3, 75-86.

[12]. Entrepreneurial Orientation and Business Performance of Women-Owned Small and Medium Enterprises in Malaysia: Competitive Advantage as a Mediator . (2013). International Journal of Business and Social Science.Vol. 4 No. 1.

[13]. Gyulavari, T., and Kolos, K. (2015). The Impact of Proactive Strategies on Market Performance in Economic Downturn: the Case of Hungary. Proceedings Of The 6th Emac Regional Conference. Vienna: Vienna Universityof Economics and Business. .

[14]. Hatani, L., Djumahir, Z. D., and Wirjodirjo, B. (2013). Competitive Advantage as Relationship Mediation between Supply Chain Integration and Fishery Company Performance In Southeast Sulawesi (Indonesia). IOSR Journal of Business and Management, Vol. 6, I. 5,01-14.

[15]. Hilgers, T. (2011). Investigating the relationship between international entrepreneurial orientation and firm performance of international small firms;A multiple case study of small manufacturing firms in the Netherlands.

[16]. Ismail A. I., Rose R. C., Abdullah H. and Uli J. (2010) The relationship between organisational competitive advantage and performance moderated by the age and size of firms. (2010). Asian Academy of Management Journal Vol. 15, No. 2, 157-173.

[17]. Karanja P. (2012) Challenges Hindering Sustainability of Small and Medium Family Enterprises After the Exit of the Founders in Kenya.Unpublished PhD Thesis, Jomo Kenyatta University of Agriculture and Technology,Nairobi.

[18]. Kimani, G. W. (2015). Entrepreneurial Orientation and the Performance of Micro nd Small Enterprises in the Publishing Industry in Kenya.

[19]. Kiprotich, S., Kimsop, J., and Kemboi, A. (2015). Moderating effect of social networking on the relationship between Entreprenual Orientation and Performance of Small and Medium Enterprises in Nakuru county, Kenya. European Journal of Small Business and Entrepreneurship Research, Vol. 3, No. 2, 38-52.

[20]. Kraus, S. Rigtering, C. J., Hughes, M., and Vincent , H. (2012). Entrepreneurial orientation and the business performance of SMEs: a quantitative study from the Netherlands. 6: 161- 182.

[21]. Krawjeski, Rizmant and Malhotra, (2010) Operation Management, Processes and Supply Chain, 9th Ed, Pearson

[22]. La Hatani, L. (2013). Competitive Advantage as Relationship Mediation between Supply Chain Integration and Fishery Company Performance in Southeast Sulawesi (Indonesia). IOSR Journal of Business And Management, 6(5), 1-14. http://dx.doi.org/10.9790/487x-0650114

[23]. Lumpkin T, Dess M (2001). New business start-up and subsequent entry into self- employment, Journal of Business Venturing, 21(6):866-885

[24]. Lumpkin, G. T., and Dess, G. G. (1996). Clarifying the entrepreneurial orientation construct and linking it to performance. Academy of Management Review, 21(1), 135-172

[25]. Miles, M.B. and Huberman A.M., (1984). Qualitative Data Analysis, Sage

[26]. Miller, D. and Friesen, P.H. (1983). Strategy-making and environment: The third link. Strategic Management Journal, 4(3), 221-235.

[27]. Mugenda OM, Mugenda AG (2008). Research methods: Quantitative and qualitative.

[28]. Naldi, L. Nordqvist, M., Sjaberg, K., and Wiklund, J. (2007). Entrepreneurial Orientation, Risk Taking, and Performance in Family Firms. Family Business Review, 20(1), 33-47. http://dx.doi.org/10.1111/j.1741$\underline{6248.2007 .00082 . x}$ 
[29]. Ngoze, M. and Bwisa, H., (2014). Entrepreneurial Orientation and Financial Performance of Manufacturing Firms in Developing Countries: are Kenya's Manufacturing Firms Exempted? Available at SSRN: http://ssrn.com/abstract=2490713

[30]. Olsen, N. B. (2013). Proactive market orientations effect on export performance: A perspecitve from small Danish production companies.

[31]. Otieno, S. Bwisa, H. M., and Kihoro, J. M. (2012). Influence of Entrepreneurial Orientation on Kenya's Manufacturing Firms Operating under East African Regional Integration. International Journal of Learning and Development, Vol. 2, No.1,.

[32]. Peteraf M. A. and Barney J.B., (2003) "Unravelling The Resource-Based Tangle, Managerial and Decision Economics", vol. 24, pp. 309-323

[33]. Price, D. Stoica, M., and Boncella, R. (2013). The relationship between innovation, knowledge, and performance in family and non-family firms: an analysis of SMEs. J Innov Entrep, 2(1), 14. http://dx.doi.org/10.1186/21925372-2-14

[34]. Rumelt, R., (1981) towards a strategic theory of the firm. In R. Lamb (Ed.), competitive strategic management: 556-570. Englewood Cliffs, NJ: Prentice-Hall

[35]. Sagwa, E. V. Obonyo, P. K., and Ogutu, M. (2015). Moderating Effect of Competitive Strategy on the Relationship between Employee Outcomes and Performance of Firms Listed on the Nairobi Securities Exchange. International Journal of Sciences: Basic and Applied Research (IJSBAR). Vol. 22, No 1, 211-224.

[36]. Schillo, S. (2011). Entrepreneurial Orientation and Company Performance: Can the Academic Literature Guide Managers? Technology Innovation Management Review.

[37]. Schumpeter J (1934). The Theory of Economic Development: An inquiry into profits, capital, credit, interest and the business cycle. Cambridge: Harvard University Press.

[38]. Srinivasan, R. Rangaswamy, A., and Lilien, G.L. (2005).Turning adversity into advantage: does proactive marketing during a recession pay off? International Journal of Research in Marketing, 22, 109-125.

[39]. Venkatraman, N. (1989), Strategic orientation of business enterprises: The construct, dimensionality and measurement, Management Science, 35(8), pp.942-962.

[40]. Verhees, F. J., Klopcic, M., and Kuipers, A. (2008). Entrepreneurial Proclivity and the Performance of Farms: The Cases of Dutch and Slovenian Farmers. 12th EAAE Congress. Belgium.

[41]. Walls, M. (2005). Corporate risk-taking and performance: A 20 year look at the petroleum industry. Journal of Petroleum Science And Engineering, 48(3-4), 127-140. http://dx.doi.org/10.1016/j.petrol.2005.06.009

[42]. Yasar, F. (2010). Competitive strategies and firm performance: case study on gaziantep carpeting sector . Mustafa Kemal University Journal of Social Sciences Institute.Vol. 7,No 14, 309- 324.

[43]. Yong, H. L. Jing, W. H., and Ming, T. T. (2008). Entrepreneurial orientation and firm performance: The role of knowledge creation process.

[44]. Zahra, S.A (2003) International Expansion of U.S Manufacturing Family Businesses: The Effect of Ownership and Involvement.Journal of Business Venturing.

[45]. Zulkifli M. R., and Rosli. M. (2013). Entrepreneurial Orientation and Business Success of Malay Entrepreneurs: Religiosity as Moderator. International Journal of Humanities and Social Science.Vol. 3 No. 10. 